\title{
HENRY V, ANACHRONISM, AND THE HISTORY OF INTERNATIONAL LAW
}

\author{
CHRISTOPHER N. WARREN
}

Is Shakespeare's Henry $\mathrm{V}$ a war criminal? The question provides the arch title of John Sutherland and Cedric Watts' 2000 book of Shakespearean puzzles, but considered earnestly it tends to raise alarms within highly defended disciplinary borders in history, law, and literature. ${ }^{1}$ The idea of war crime strikes many ears as anachronistic-even absurd. So contemporary does the notion of war crime sound that it seems scandalously presentist to apply the category to Shakespeare's martial king. For many, analysing war crime in Henry V exhibits what one historian denounces as the 'confusion of our cultural and ethical expectations with those of the early modern world.' It is as though we were asking whether Henry had an iPhone-or took Viagra.

Since historicism and anachronism are important issues for early modern law and literature, the first of two main aims of this essay is to consider the problem of temporality at the interdisciplinary nexus of history, literature, and international law. Scholars in each of these overlapping fields have recently reflected on the role of anachronism in

1 John Sutherland and Cedric Thomas Watts, Henry V, War Criminal?: And Other Shakespeare Puzzles (Oxford: Oxford University Press, 2000). See also Janet M. Spencer, 'Princes, Pirates, and Pigs: Criminalizing Wars of Conquest in Henry V', Shakespeare Quarterly, 47.2 (July, 1996): 160-77; Evelyn Gajowski, ' "Mirror[s] of All Christian Kings": Hank Cinq and George Deux', in Presentism, Gender, and Sexuality in Shakespeare, ed. Evelyn Gajowski (New York: Palgrave Macmillan, 2009), 63-87.

2 Conal Condren, 'Understanding Shakespeare's Perfect Prince: Henry V, the Ethics of Office and the French Prisoners', in The Shakespearean International Yearbook, ed. Graham Bradshaw, Tom Bishop, and Laurence Wright (Burlington: Ashgate, 2009), 9.196. As Paul Stevens observes, 'war' alone is troublesome. He reminds us that Shakespeare critics tend to invest 'war' with a timeless essence, thereby obscuring the many ways that 'war' has 'changed dramatically, perhaps beyond all recognition, over the last 400 years'. See Paul Stevens, 'Henry V: Shakespeare and the Sacralization of War', forthcoming in Cambridge Companion to Shakespeare and War, ed. Paul Stevens and David Lowenstein. I am grateful to Prof. Stevens for sharing this essay prior to publication. 
their analyses, yet the implications for the study of early modern literature and international law have not yet been considered directly. The second, related aim concerns how and whether international law should influence our interpretations of Henry V. My contribution in this regard is to propose as a new context for Shakespeare's play a littleknown humanist disputation by the civil lawyer Alberico Gentili, De armis Romanis (1599). I argue that a more expansive, generically sensitive historicism than Conal Condren's may be in order before we dismiss the question of Henry's war crimes as 'the cultural narcissism of displaced indignation.' ${ }^{3}$ Together with Henry V, De armis Romanis affirms an important point about historicism and anachronism once made by David Norbrook: '[w] have a word for anachronism, but we need and lack a word ... for an equal and opposite error, which "blindly insists that current events have yet to occur".'4 Indeed, Henry $V$ and De armis Romanis illustrate why early modernists interested in international law need not reject synchronic historicism for explicitly anachronistic or presentist approaches. Instead, we can pay further attention to a juridical approach to the international past cultivated in the early modern period alongside the rise of international law-an approach closely linked with literary epistemologies.

\section{ANACHRONISM AND INTERNATIONAL LEGAL METHOD}

'To understand [Henry V]', Conal Condren argues, 'requires we both recognize and try to put to one side our own senses of moral and political rectitude. ${ }^{5}$ Condren dutifully invokes what Constatin Fasolt in his book The Limits of History (2004) calls historians' 'most basic principle of method: thou shalt place everything in the context of its time. ${ }^{6}$ And yet there are many in international criminal law for whom it makes perfect sense to ask whether Shakespeare's Henry V was a war criminal. It has long been accepted in international humanitarian law that 'the first international war crime trial' took place in 1474, with the trial of Charles the Bold's military lieutenant Peter von Hagenbach. ${ }^{7}$ Peter von Hagenbach, it is widely agreed, was held to account in 1474 by a quasi-international

${ }^{3}$ Condren, 'Understanding Shakespeare's Perfect Prince', 208.

${ }^{4}$ David Norbrook, Poetry and Politics in the English Renaissance, rev. edn (Oxford: Oxford University Press, 2002), 288. Norbrook is quoting David Wootton, 'Leveller Democracy and the Puritan Revolution', in The Cambridge History of Political Thought, 1450-170o, ed. J. H. Burns and Mark Goldie (Cambridge: Cambridge University Press, 1991), 417.

${ }^{5}$ Condren, 'Understanding Shakespeare's Perfect Prince', 196.

${ }^{6}$ Constantin Fasolt, The Limits of History (Chicago: University of Chicago Press, 2004).

7 Georg Schwarzenberger, 'A Forerunner of Nuremberg: The Breisach War Crime Trial of 1474', The Manchester Guardian, 28 September 1946; Gregory S. Gordon, 'The Trial of Peter von Hagenbach: Reconciling History, Historiography, and International Criminal Law', in The Hidden Histories of War Crimes Trials, ed. Kevin Heller and Gerry Simpson (Oxford: Oxford University Press, 2013), 13-49. 
tribunal for crimes that included 'divers extortions and outrages', among them executing 'men of honour ... without any forme of Lawe. ${ }^{8}$ To similar effect, lawyers have found Shakespeare's Henry V exhibiting the 'idea' of war crime and have credited Shakespeare's contemporary, the civil lawyer Alberico Gentili, with 'anticipating international criminal tribunals.' There's a puzzle here. The question of war crime in Henry V seems at once dishonourably presentist from the perspective of history and rigorously historicist from the perspective of law. What gives?

The charged question of war crime highlights some important methodological suppositions that quietly influence the questions scholars ask, frame the interpretations we give, and condition our receptivity to those interpretations. Whether or not war crime is anachronistic when applied to the early modern period-an argument I reject with some qualifications in part II-the very question of anachronism highlights meaningful yet rarely discussed differences among this volume's main interpretative communities in law, history, and literary studies. As Anne Orford has observed, 'Law and history stand on the opposite sides of the dividing line between present obligations and archaic traditions. The self-imposed task of today's contextualist historians is to think about concepts in their proper time and place-the task of international lawyers is to think about how concepts move across time and space. ${ }^{10}$ 'International legal method', in other words, is 'necessarily anachronistic." What then of literary studies? Literature can mean both synchronically and diachronically, in its own moment and potentially across vast temporal distances. Orford's line, therefore, cuts through the heart of literary scholarship. On the one hand, historicists (new and old) generally suppose that 'a period often has a set of values that are not directly applicable, or sometimes even comprehensible, to other

8 Schwarzenberger, 'A Forerunner of Nuremberg: The Breisach War Crime Trial of 1474'; Georg Schwarzenberger, International Law as Applied by International Courts and Tribunals: The Law of Armed Conflict (London: Stevens, 1968), 2.462-4; H. McCourbey, 'War Crimes: The Criminal Jurisprudence of Armed Conflict', Military Law and Law of War Review, 31 (1992): 171; Gordon, 'The Trial of Peter von Hagenbach: Reconciling History, Historiography, and International Criminal Law'; Joaquín Alcaide Fernández, 'Hostes Humani Generis: Pirates, Slavers, and Other Criminals', in The Oxford Handbook of the History of International Law, ed. Bardo Fassbender and Anne Peters (Oxford: Oxford University Press, 2012); Philippe de Commynes, The Historie of Philip de Commines Knight, Lord of Argenton (London: Ar. Hatfield, for I. Norton, 1596), 122; Jean de Serres, A General Inuentorie of the History of France, ed. Pierre Matthieu, trans. Edward Grimeston (London: George Eld, 1607), 249.

9 McCourbey, 'War Crimes', 170; Theodor Meron, 'International Humanitarian Law from Agincourt to Rome', International Law Studies, 75 (2000): 306.

${ }^{10}$ Anne Orford, 'The Past as Law or History?: The Relevance of Imperialism for Modern International Law', International Law and Justice Working Papers, IILJ Working Papers, no. 2 (2012), <http://www.iilj. org>.

${ }^{11}$ Anne Orford, 'On International Legal Method', London Review of International Law, 1.1 (2013): 175. Emphasis mine. Orford proposes an international legal method less indebted to Cambridge School intellectual history, exemplified most prominently by Quentin Skinner, 'Meaning and Understanding in the History of Ideas', in Visions of Politics, 3 vols (Cambridge: Cambridge University Press, 2002), 1.57-89. For a contextualist rejoinder founded in the possibility of rhetorical manipulation, see Andrew Fitzmaurice, 'Sovereign Trusteeship and Empire', Theoretical Inquiries in Law, 16.2 (2015): 468-71. 
periods or epochs. ${ }^{12}$ They find meaning on the temporal axis of synchronicity. On the other hand, formalists, presentists, and others attend to the diachronic axis, remaining 'wary of reconstructing a binary opposition between past and present' and emphasizing themes such as continuity, tradition, aesthetics, cross-temporal dialogue, and deep time. ${ }^{13}$ Scholars of the latter sort are largely unfazed by charges of anachronism, which some even make an explicit goal. Strange bedfellows emerge in the process. On its face, the counter-historicist injunction to 'always anachronize', a retort to Frederic Jameson's 'always historicize', appears altogether compatible with international legal method, even though neither camp has explicitly recognized the affinity. ${ }^{14}$

The historicist principle that everything must be placed in its time has recently undergone criticism from legal and literary scholars as well as some historians proposing a return to the longue durée, but it is a position that historian Brad Gregory elaborates elegantly when he writes, 'Only historians have the time and training to pursue past experience as it was lived and construed. Without that effort, past worlds will be utterly lost, not only because human experience is fleeting, but because even the ideal of reconstructing it will have passed as so much grist through the mill of the theories and commitments of the moment. ${ }^{\prime 1}$ Dicta such as these, in Fasolt's account, have far more to do with law than we normally allow. It is precisely historians' basic principle of method that keeps history distinguishable from law. Lawyers and judges use the past instrumentally, as necessitated by the case at hand; but historians' core prohibition on anachronism ensures-or seeks to ensure-that instrumental legal needs do not impinge on historiography. As Fasolt writes, the necessity to contextualize,

keeps historians from committing anachronism. It places the past under a great taboo in order to prevent a kind of chronological pollution. No one who violates that great taboo may claim to be a true historian. The past is sacred; the present is profane. Anachronism profanes the past by mixing past and present. ... All other sins can be forgiven, but not this one. Anachronism is the sin against the holy spirit of history. Show that a historian has unwittingly infected the interpretation of the past with some particle of the present, and you have shown the historian not only to have failed at the task, but to have failed shamefully. ${ }^{16}$

12 Paul Stevens, 'The New Presentism and Its Discontents: Listening to Eastward Ho and Shakespeare's Tempest in Dialogue', in Rethinking Historicism from Shakespeare to Milton, ed. Ann Baynes Coiro and Thomas Fulton (Cambridge: Cambridge University Press, 2012), 139.

${ }^{13}$ Evelyn Gajowski, 'Beyond Historicism: Presentism, Subjectivity, Politics', Literature Compass, 7.8 (2010): 681. Further examples include Wai-chee Dimock, 'A Theory of Resonance', PMLA, 112.5 (1997): 1060; Simon Jarvis, 'Prosody as Tradition', Dalhousie Review, 79.2 (1999): 151-72; Stanley Fish, 'Why Milton Matters; Or, Against Historicism', Milton Studies, 44 (2005): 1-12; Jonathan Gil Harris, Untimely Matter in the Time of Shakespeare (University of Pennsylvania Press, 2008); Marshall Grossman, 'Limiting History', in Rethinking Historicism from Shakespeare to Milton, ed. Ann Baynes Coiro and Thomas Fulton (Cambridge: Cambridge University Press, 2012), 65-84.

${ }^{14}$ Gajowski, 'Beyond Historicism', 678.

${ }_{15}$ Brad S. Gregory, Salvation at Stake: Christian Martyrdom in Early Modern Europe (Cambridge, MA: Harvard University Press, 1999), 15.

${ }^{16}$ Fasolt, The Limits of History, 6. 
Historians-and 'only historians', according to Gregory-guard the citadel of the past against the pressures of the present. They protect the past from distorting external threats like moralism and 'judicialization, ${ }^{17}$ The historian Henry Rousso, an expert on Vichy France who, citing a fundamental incompatibility between historical and legal methods, has refused to testify in late twentieth-century French war crimes trials, contends that history differs from law precisely by 'giv[ing] us a better understanding of the distance that separates' the past and the present. ${ }^{18}$

And yet that same gap between past and present that charges of anachronism achieve is also, for thinkers like Fasolt and Rousso, law's very condition of possibility. By marking off something called the past from something called the present, 'Historians clear a space in time so that it may be occupied by individuals no longer tied to custom and tradition. ${ }^{19}$ Law, understood as something binding, here and now, is possible precisely because historians have carved out a differentiated 'past' from the temporal flux. Modern people, as Fasolt puts it, 'could not imagine life if their present were cluttered by the laws of ancient Rome, the science of Aristotle, and the morality of Saint Augustine.20 At stake in the charge of anachronism, then, is the very possibility of laws that feel somehow 'ours'. Such perception of historical distance is critical, according to advocates of this line of thought. A properly historical epistemology is above all an 'apprenticeship in liberty, since the historical being is one who frees him- or herself ... to impose his or her own path. ${ }^{21}$ For Fasolt, borrowing from legal historian William Maitland, the 'rents' historians make in the 'seamless web' of history 'leave us to move on our own initiative along the trajectory of time into a future that will turn out to be another here and now.'22 'They do not oblige us to shoulder any responsibilities other than those to which we have consented of our own free will', he concludes. ${ }^{23}$ Fasolt's primary concern in The Limits of History is an early modern 'historical revolt' in which highly partisan humanists practised new historical methods to help liberate fledgling sovereigns from imperial and papal control. ${ }^{24}$ The sovereign 'right to legislate' emerged alongside, and often as a result of, early modern humanists' assault against anachronism. ${ }^{25}$

Extrapolating from Fasolt's account, we can say that historicism and international law enjoy a partly causal relationship. A tool for sovereign self-fashioning, the

${ }^{17}$ Henry Rousso, The Haunting Past: History, Memory, and Justice in Contemporary France, trans. Ralph Schoolcraft (Philadelphia: University of Pennsylvania Press, 2002), 50; Richard J. Evans, 'History, Memory, and the Law: The Historian as Expert Witness', History and Theory, 41.3 (2002): 330.

${ }_{18}$ Rousso, The Haunting Past, 8; Richard Wilson, Writing History in International Criminal Trials (Cambridge and New York: Cambridge University Press, 2011), 7.

19 Fasolt, The Limits of History, 8.

${ }^{20}$ Fasolt, The Limits of History.

${ }^{21}$ Rousso, The Haunting Past, 8.

${ }^{22}$ Fasolt, The Limits of History, 227, 230.

${ }^{23}$ Fasolt, The Limits of History, 230.

${ }^{24}$ Fasolt, The Limits of History, 16-22; George H. Nadel, 'Philosophy of History before Historicism', History and Theory, 3.3 (1964): 291-315; Stevens, 'The New Presentism and Its Discontents: Listening to Eastward Ho and Shakespeare's Tempest in Dialogue', 139.

${ }^{25}$ Fasolt, The Limits of History, 201. 
idea of anachronism helped create new conceptual spaces between previously unified regions-helped create, that is, the constitutive inter- of international law. The recent 'historiographical turn' in international law, however, has nevertheless remained wary of full-fledged historicism. ${ }^{26}$ Randall Lesaffer writes that in international law, "history is functional and is dictated by current needs. It is rarely born out of curiosity about the past itself ${ }^{27}$ Siding with historians like Condren and Gregory, Lesaffer counts international law's functionalist presentism as a distinct mark against current practice in international legal history, but critical legal scholars like Anne Orford, Martti Koskenniemi, and Rose Parfitt embrace the very version of international law historicism that Lesaffer laments.

Critical legal historians advocate for a distinctly 'juridical method' defined by a salutary 'intermingling' of past and present. ${ }^{28}$ According to Hans-Georg Gadamer and his followers at least, such intermingling is, in any case, inevitable. Writing about legal hermeneutics in Truth in Method, Gadamer declares, 'A historical hermeneutics that does not make the nature of the historical question the central thing, and does not inquire into a historian's motives in examining historical material, lacks its most important element. ${ }^{29}$ On this view, historians charging others with anachronism overestimate their capacity to distance themselves from concerns of the moment. Either that, or they dissemble.

Tropes of international juridical method are probably more familiar to literary scholars when reframed as 'presentism', a literary method that calls on scholars to own up to the repressed political and moral commitments that condition interpretations. Arguably, both projects 'seek out salient aspects of the present as a crucial trigger for investigations', taking as their 'centre of gravity ... "now", rather than "then" . ${ }^{30}$ Legal thinkers and presentists charge that historians' historicism is morally underequipped, unable to supply 'value judgments' to accompany what Philip Sidney had already called the 'bare was' of history. ${ }^{31}$ In Koskenniemi's words, historians' history suffers from 'an historical relativism [that] ends up suppressing or undermining efforts to find patterns

26 George Rodrigo Bandeira Galindo, 'Martti Koskenniemi and the Historiographical Turn in International Law', European Journal of International Law, 16.3 (2005): 539-59.

27 Randall Lesaffer, 'International Law and Its History: The Story of an Unrequited Love', in Time, History and International Law, ed. Matthew C. R. Craven, M. Fitzmaurice, and Maria Vogiatzi (Leiden: M. Nijhoff, 2007), 29.

28 Orford, 'On International Legal Method'; Martti Koskenniemi, 'Vitoria and Us: Thoughts on Critical Histories of International Law', Rechtsgeschichte Legal History-Zeitschrift Des Max-PlanckInstituts Für Europäische Rechtsgeschichte, 22 (2014): 124. In calling for a return to longue durée history while emphasizing questions of international law and governance, Jo Guldi and David Armitage strike an intriguing middle ground in The History Manifesto (Cambridge: Cambridge University Press, 2014).

${ }^{29}$ Hans Georg Gadamer, Truth and Method, trans. W. Glen-Doepel, Joel Weinsheimer, and Donald G. Marshall, 2nd rev. edn (New York: Continuum, 2004), 334.

30 Terence Hawkes, Shakespeare in the Present (New York: Routledge, 2003), 22.

${ }^{31}$ Andrew Hadfield, 'Has Historicism Gone Too Far: Or, Should We Return to Form?', in Rethinking Historicism from Shakespeare to Milton, ed. Ann Baynes Coiro and Thomas Fulton (Cambridge: Cambridge University Press, 2012), 24-5. 
in history that might account for today's experiences of domination and injustice. ${ }^{32}$ For legal scholars to proceed in the way of historians, then, is to abdicate their constitutive 'juridical stance. ${ }^{33}$

It is true of course that international legal history can be an instrumental exercise in justification. The so-called 'Breisach War Crime Trial of 1474' was successfully introduced into legal historiography by the refugee jurist Georg Schwarzenberger, in the midst of the deliberations at Nuremberg. ${ }^{34}$ As such, the barely suppressed role of international legal history in identifying this 'forerunner to Nuremberg' was to legitimate the international legal actions against Nazi defendants.

But freer congress between past and present in the hands of recent critical legal historians is not necessarily intended to serve up sources and precedents. Instead, critical histories of international law seek greater openness to uncomfortable ideas like empire and domination that might otherwise be externalized from the domain called 'Law' and projected onto a screen called 'History. ${ }^{35}$ Whereas historians' historicism and certain older international legal histories ally to shore up international law's legitimacy, critical international legal method interrogates that legitimacy by rejecting a metaphysical gap between past and present. International legal method insists that international law is not exclusively an artefact of the (enlightened) present. Since it bears ideological baggage from the past, it is not exclusively 'ours'.

Coming at such questions from the perspective of early modern studies, it becomes possible to identify in both international legal method and literary presentism a subtle persistence of a Renaissance philosophy of history founded in forensic rhetoric, exemplarity, legal analysis, and moral critique-a philosophy of history that historicism most certainly injured but did not fully eliminate. If early modern historicism erected a wall intended to disable problematic exchanges between past and present like that now found in presentism and international legal method, that wall had not yet reached its full height by the 159 os when people like Gentili and Shakespeare were writing. Using historicism's own lens, we can begin to see evidence of early modern literature and law resisting the partition between past and present posited by historicism. Early modern historicism enthroned the past as sovereign, immune from legal scrutiny. But as I illustrate in the following section, international legal method operates with a renovated Renaissance philosophy of history partly because thinkers like Shakespeare and Gentili, writing at the dawn of historicism, deployed genres that facilitated meaning-making along both the synchronic and diachronic axes. Vertex-like works like Henry V and De armis Romanis point interpreters along divergent paths, allowing for contemporary resonance and also transmitting legal meaning across time. A result is that chronologically

${ }^{32}$ Koskenniemi, 'Vitoria and Us: Thoughts on Critical Histories of International Law', 124.

${ }^{33}$ Rousso, The Haunting Past, 53.

${ }^{34}$ Gordon, 'The Trial of Peter von Hagenbach: Reconciling History, Historiography, and International Criminal Law'; Detlev F. Vagts, 'International Law in the Third Reich', The American Journal of International Law, 84.3 (1990): 661-704.

35 Rose Parfitt, 'The Spectre of Sources', European Journal of International Law, 25.1 (2014): 302. 
later interpreters can, in full fidelity with the authors' own ambitions, take on a juridical stance in asking whether Henry violated the laws of war.

Some critical legal historians may suggest that anachronism is fundamental to international legal method, but Orford herself gives an even more compelling model for 'juridical thinking' in the double temporality of Renaissance art, in which works of visual art are said to gesture at once to an immediate social and material context but also to a broader, more ambitious timescale associated with diachronicity and the longue durée. ${ }^{36}$ Indeed, 'Law, like art, holds together two ideas about time. ${ }^{37}$

\section{Making The InTERNATIONAL CASE}

In Jean Bodin's Method for the Easy Comprehension of History (1566), the author wonders aloud 'whether historians ought to praise or to vituperate and to express judgements about the matter under discussion.38 Historians' 'juridical stance' is precisely what historicism sought to expunge. ${ }^{39}$ Bodin himself equivocates on the question of historians' judgements, but not before remarking that 'the prejudice of the historians detracts greatly from the events, because they seem to wish to inculcate in the minds of inexperienced readers opinions that are questionable. ${ }^{30}$ Seeds of the contemporary debate had been sown.

The Oxford jurist Alberico Gentili soon took up the cudgels for a legally inflected past in his seminal work on the laws of war, De iure belli libri tres (1598). Minimizing Bodin's own reservations, Gentili complained that Bodin's 'bare recital of history' left too large a gap between examples and precepts. ${ }^{41}$ 'Because of the diversity and contradictory nature of examples ...' he wrote, 'one could not easily derive from this treatment any system of law.42 In chapter 26 of that same work, Gentili pointedly rejected the "bare recital of history' again when he denounced Henry V's actions at Agincourt, actions dramatized powerfully-if somewhat ambiguously-when Shakespeare's Henry orders his soldiers to execute their prisoners. 'I cannot praise the English who, in that famous battle in which they overthrew the power of France, having taken more prisoners than the number of their victorious army and fearing danger from them by night, set aside those of high rank and slew the rest. ${ }^{3}$ 'Jumping o'er times' as Henry V's Chorus would say, the

36 Orford, 'On International Legal Method', 176. See Grossman, 'Limiting History', 69.

37 Orford, 'On International Legal Method', 166, 176.

${ }^{38}$ Jean Bodin, Method for the Easy Comprehension of History, trans. Beatrice Reynolds

(New York: Norton, 1969), 51.

39 Rousso, The Haunting Past, 53.

40 Bodin, Method for the Easy Comprehension of History, 51.

${ }^{41}$ Alberico Gentili, De iure belli libri tres, 2 vols, trans. John Carew Rolfe (Oxford: Clarendon Press, 1933), 2.4.

42 Gentili, De iure belli libri tres, 2.4 .

${ }^{43}$ Gentili, De iure belli libri tres, 2.212.

title c

they:

W]

lish I

Turk:

form

'the $t$

self o

som $\epsilon$

gene:

sycol

equit

royal

on th

$\mathrm{Se}$

Shak

natic

of re

Gent

parti

Hent

armi

and

nific

44

librit

45

2009

46

Inter

47

Midd

Tradi

Genti

Influe

(Burl

1580-

48

Groti

of Ex

Revu

Bene

Natic

Gent

King: 
title of Gentili's chapter mobilizes the historical lesson for the present: 'Of Captives: that they are not to be Slain' (Prologue, 29).

Whereas Shakespeare's Henry and his Chorus of apologists appear at pains to establish Henry as a just Christian warrior-distinct, for example, from enemies like the Turks, who in Henry's allusions 'represent ... the antithesis of supposedly native English forms of communal and political life'-Gentili's text lumps Henry's war crimes with 'the barbarous savagery of the Turk, who slew four thousand prisoners, to relieve himself of their burden. ${ }^{44}$ Shakespeare's Henry, then, quite possibly was a war criminal for some early modern elites, to say nothing of the moral intuitions of early audiences more generally. Indeed, while Shakespeare's Chorus, Gower, and his Welsh Captain Fluellen sycophantically buttress Henry's self-mystification, the play on the whole licenses an equitable interpretive framework that, as Lorna Hutson has shown, radically demystifies royal authority. ${ }^{45}$ It is a way of interpreting fundamental to international law-premised on the 'jurisdiction of the interpreter' to 'measure and judge the acts of sovereigns. ${ }^{46}$

Several recent scholars have noticed important connections between Gentili and Shakespeare, but the text of Gentili's that best illustrates the particularities of international law's own historicism may not be his De iure belli, which has been the focus of recent studies by Theodor Meron, Paula Pugliatta, and Rosanna Camerlingo, but Gentili's remarkable De armis Romanis, issued in two parts in 1590 and $1599 .{ }^{47}$ Published partially in quarto in 1590 and then in an expanded octavo in 1599, the same year of Henry V's composition, with each dedicated to Robert Devereux, the Earl of Essex, De armis Romanis has recently attracted renewed attention from intellectual historians and historians of international law; literary scholars have been slower to note its significance. ${ }^{48}$ It is not a trait habitually ascribed to lawyers, and it is one that Condren

\footnotetext{
${ }^{44}$ Benedict S. Robinson, 'Harry and Amurath', SQ, 60.4 (December, 2009): 400; Gentili, De iure belli libritres, 2.212.

${ }^{45}$ Lorna Hutson, 'Imagining Justice: Kantorowicz and Shakespeare', Representations, 106.1 (May, 2009): 118-42.

${ }^{46}$ Peter Goodrich, 'On the Relational Aesthetics of International Law', Journal of the History of International Law, 10 (2008): 321.

47 Theodor Meron, Henry's Wars and Shakespeare's Laws: Perspectives on the Law of War in the Later Middle Ages (Oxford: Oxford University Press, 1993); Paola Pugliatti, Shakespeare and the Just War Tradition (Burlington: Ashgate, 2010); Rosanna Camerlingo, 'Henry V and the Just War: Shakespeare, Gentili and Machiavelli', in Machiavellian Encounters in Tudor and Stuart England: Literary and Political Influences from the Reformation to the Restoration, ed. Alessandro Arienzo and Alessandra Petrina (Burlington: Ashgate, 2013), 103-19. See also Christopher N. Warren, Literature and the Law of Nations, 1580-1680 (Oxford: Oxford University Press, 2015), 62-95.

${ }^{48}$ Richard Tuck, The Rights of War and Peace: Political Thought and the International Order from Grotius to Kant (Oxford: Oxford University Press, 1999); Kaius Tuori, 'Alberico Gentili and the Criticism of Expansion in the Roman Empire. The Invader's Remorse', Journal of the History of International Law/ Revue D'histoire Du Droit International, 11.2 (2009): 205-19, doi:10.1163/138819909X12468857001389; Benedict Kingsbury and Benjamin Straumann, eds, The Roman Foundations of the Law of Nations: Alberico Gentili and the Justice of Empire (New York: Oxford University Press, 2011); Alberico Gentili, The Wars of the Romans: A Critical Edition and Translation of De armis Romanis, ed. Benedict Kingsbury and Benjamin Straumann, trans. David Lupher (New York: Oxford University Press, 2011).
} 
contends was all but historically impossible, but Gentili too was capable of something approaching 'negative capability'. A previously unnoticed allusion to De armis Romanis may even be found in Henry V 3.3 where Fluellen discourses on the 'wars of the Romans', a direct English translation of Gentili's title (3.3.26-7)..$^{49}$ The emendation that T. W. Craik proposes for a subsequent Fluellen line brings that text closer to Gentili's title as well. Where the First Folio gives 'disciplines of the Warre, the Roman Warres', Craig proposes to make the 'Warre' on the basis of the Folio's cramped spacing $(3.3 .40-1){ }^{50}$

Of all of Shakespeare's characters, it is certainly Fluellen who echoes Gentili's language most noticeably, but De armis Romanis can also be felt in Henry $V$ in more subtle ways: in the play's apparently simultaneous praise and condemnation of its title character; its depiction of Celtic warriors in a proto-British army; and the play's interest, in David Quint's words, in 'dramatizing rather than concealing ... the literary act which recreates the event.5. Insofar as 'the event' of Henry $V$ is one that continues to elicit judgement, this is where my two main aims in this essay intertwine: judgement indicates a juridical approach to the past rather than a strictly historicist one. 'A problem-event that has animated some kind of judgment' is what Lauren Berlant calls a 'case.52 The notion of the causa or case was pervasive in early modern culture, and it was especially potent in dramatic composition and formal rhetoric, where it was regularly equated with the Greek hypothesis, literally placing under. ${ }^{53}$ If historicism was a commitment to the 'bare' event, shorn of legal meaning for the present, the problem that Shakespeare and Gentili confronted was how exactly to place the international past under legal scrutiny. Their works give us two related examples of making cases from international events, of hypothesizing the international past skilfully enough to prompt generalizable judgements about the conduct of war. ${ }^{54}$

49 Meron found 'no evidence that the sixteenth-century writers of jus gentium influenced Shakespeare either directly or indirectly'. See Meron, Henry's Wars and Shakespeare's Laws, 11.

${ }^{50}$ William Shakespeare, King Henry V, ed. T. W Craik, Arden Shakespeare 3rd edn

(New York: Routledge, 1995), 3.2.98. I am grateful to Lorna Hutson for bringing Craik's emendations to my attention.

${ }^{51}$ David Quint, ' “Alexander the Pig”: Shakespeare on History and Poetry', Boundary 2, 10.3 (1982): 49-67.

${ }^{52}$ Lauren Berlant, 'On the Case', Critical Inquiry, 33.4 (June, 2007): 663-72.

53 Wesley Trimpi, Muses of One Mind: The Literary Analysis of Experience and Its Continuity (Princeton: Princeton University Press, 1983), 25. See further Kathy Eden's illuminating essay in this volume.

54 Essex is an important connection between the two works as well. So admired by Gentili that Gentili asked Essex to be godfather and namesake to his son, Robert, Essex also appears in Henry V in the Chorus's allusion to his 1599 campaign in Ireland. Of Act 5's comparison of Henry to 'the general of our gracious empress, / ... from Ireland coming, / Bringing rebellion broached on his sword', Gary Taylor writes that it is 'the only explicit, extra-dramatic, incontestable reference to a contemporary event anywhere in the canon'. See Gary Taylor, 'Introduction', in Henry V (Oxford: Oxford University Press, 1982), 7. Essex himself had published a manual for soldiers entitled Lawes and Orders of Warre Established for the Good Conduct of the Service in Ireland (1599), and the play's emphasis on discipline in the camps gives reason to think that Shakespeare drew from that work as well. 
Critical receptions of Henry $V$ leave little doubt that Shakespeare successfully created an artefact prompting judgement. What just about everyone knows by now about Shakespeare's Henry $V$ is that it is a play 'virtually daring us to choose one of the two opposed interpretations it requires of us. ${ }^{55}$ Henry $V$, it is said, makes a 'double assertion'; ${ }^{56}$ there's an 'eloquent discrepancy between the glamor of the play's rhetoric and the reality of its action'; ${ }^{57}$ Henry $V$ is 'not ... able to decide between an optimistic and a pessimistic model'; ${ }^{58}$ it is 'schizophrenic'; ${ }^{59}$ it traffics in the 'breaches' between heroism and antiheroism. ${ }^{60}$ It exhibits 'disillusioned ambivalence' and creates 'rival gestalts'.61 Careful readers have long seen how the play lends itself to debates such as that staged in Washington, DC in 2004, at which Iraq war opponents including Arianna Huffington faced off over Henry $V$ with Iraq war supporters including Christopher Hitchens and neoconservative writer Kenneth Adelman, the latter already notorious for declaring George W. Bush a new Henry V and the US invasion of Iraq a would-be 'cakewalk.' ${ }^{62}$ In addition to suggesting how the play itself invites presentist application, such debates also indicate how difficult it is to reduce Henry to an idealized Christian warrior or to a purely Machiavellian imperialist. The play, it seems, will not speak mono-vocally as either apology or critique.

Henry's double order to kill the French prisoners is both the most famous and the most instructive example, for it highlights Shakespeare's interest in competing historiographies and their relations to case-making in international law. Aided by apologia by Fluellen and Gower, the play quite purposefully makes available the view that 'the King most worthily hath caused every soldier to cut his prisoner's throat'-this on the premise that the French had previously undertaken 'as arrant a piece of knavery ... a can be offert', attacking the English servant boys, which Fluellen-again sounding here much like Gentili-declares 'against the law of arms' (4.7.2-10). When next we meet Henry, later in the scene, he thunders, 'I was not angry since I came to France / Until this instant'

55 Norman Rabkin, 'Rabbits, Ducks, and Henry V', SQ, 28.3 (July, 1977): 279.

56 Pugliatti, Shakespeare and the Just War Tradition, 201.

57 Rabkin, 'Rabbits, Ducks, and Henry V', 292.

58 Paola Pugliatti, 'The Strange Tongues of Henry V', The Yearbook of English Studies, 23 (1993): 253.

${ }^{59}$ Camerlingo, 'Henry V and the Just War: Shakespeare, Gentili and Machiavelli', 104.

60 Maurice Hunt, 'The "Breaches" of Shakespeare's The Life of King Henry the Fifth', College Literature, 41.4 (2014): 7-24.

${ }^{61}$ Christopher Highley, Shakespeare, Spenser, and the Crisis in Ireland (Cambridge: Cambridge University Press, 2007), 135; Rabkin, 'Rabbits, Ducks, and Henry V', 296.

${ }^{62}$ Bob Thompson, 'The King and We, Henry V's War Cabinet: Mock Debate at Shakespeare Theater Has Familiar Ring', The Washington Post, 18 May 2004. Of the many audiences who have noted 'uncanny parallels' between George W. Bush and Shakespeare's Henry V, particularly following the Iraq War, most if not all have missed a critical point: the neoconservative effort to promote another Iraq war involved flattering George W. Bush into similitude with Henry V. As indicated by Ken Adelman's comparison in November 1999, the neoconservative effort was already underway well before 11 September 2001. That the invasion of Iraq would eventually come to resemble the invasion of France wasn't just an uncanny repetition of the Shakespearean narrative but the outcome of Iraq hawks' successful presentist campaign to mould the Bush presidency. See Ken Adelman, 'Not Lady Macbeth: Washington's Full of Shakespeare Characters', Washingtonian Magazine, 1 November 1999. 
(4.7.53-4). He shortly declares, 'we'll cut the throats of those we have, / And not a man of them that we shall take / Shall taste our mercy' (4.7.61-3). Excellent lieutenants, Gower and Fluellen have already prepared the preferred audience response.

The seriousness with which Gower and Fluellen treat the attack on the servant boys makes Henry's retaliation appear proportional, comprehensible-indeed, right. Condren, for whom the dominant critical view of 'creative ambiguation' remains historically implausible, sides with Henry and his encomiasts, expressing it thus: 'tit for tat ... not to take revenge would provide precedent for the acceptability of such baggage train murder in the future. ${ }^{63}$ The problem, as several critics have pointed out, is that Henry in the previous scene has already commanded that 'every solder kill his prisoners' following the realization that 'The French have reinforced their scattered men' (4.6.36-7). In other words, Henry twice declares his intention that the prisoners be killed-the first time before he's heard that the boys have been attacked-before he's even grown angry, and that on his own account. The Gower and Fluellen exchange that follows Henry's harsh order masks the fundamental chronology. Henry commits war crime according the first version, lawful retaliation in the second. The order to kill the prisoners occurs the first time as tragedy, the second time as law.

Nor is the order to kill the prisoners the play's only invitation for juridical thinking about the international past. Gadfly soldier Michael Williams introduces the fraught question of whether Henry's 'cause be not good', where 'cause' straddles meanings that include Henry's internal motivation but also, more to the point, his legal case (4.1.133). ${ }^{64}$ Henry's is a legal case in the same general sense that warfare was 'arbitrament of swords', trial by battle (4.1.59). But the cause or case here is grounded in particularities, and mediated by Canterbury's putatively charitable 'reading' of the Salic law (1.2.14). When Henry invites Canterbury to 'justly and religiously unfold / Why the law Salic that they have in France / Or should or should not bar us in our claim, his invitation remains coloured by the possibility that his true intent is a legal whitewash (1.2.10-12). Canterbury's long discourse on the casus belli prompts Henry to cut to the chase: 'May I with right and conscience make this claim?' (1.2.96). Canterbury assuages Henry's apparent scruples even more vigorously than might be expected: 'The sin upon my head, dread sovereign!' (1.2.97, emphasis mine). If the play does little to extinguish the (juridical) suspicion that the war was cooked up as a pretext 'to busy giddy minds / With foreign quarrels', exactly as Henry's father had advised ( 2 Henry IV, 4.5.213-14), it does even less to deter a conclusion of priestly collusion. Henry may be enforcing a rightful claim, akin to filing suit, yet he may also have found in the prelates' tainted interests a convenient vehicle for his own. Equally ripe for legal inquiry is the oration at Harfleur's gates, which remains artfully poised between wise tactics and savage threats. It may be 'almost impossible to render any clear verdict on where Shakespeare stands' on Henry's criminality, as John

63 Condren, 'Understanding Shakespeare's Perfect Prince', 195, 203.

${ }^{64}$ On causa as motive, see Lorna Hutson, Circumstantial Shakespeare (Oxford: Oxford University Press, 2015). Hutson's The Invention of Suspicion (Oxford: Oxford University Press, 2007) beautifully underlines the connection between literary character and legal suspicion alluded to below. 
Sutherland puts it, but it is critical to notice the literary techniques that invite interpreters, even within the play itself, to try. ${ }^{65}$

Drawing Gentili more fully into this account, we can observe that, like Henry V, De armis Romanis frustrates the search for clear doctrine, and as such, has been difficult to assimilate into narrow histories of international law. Yet its genre tells an even richer story about the history of international law by showing how early modern writers placed the past under legal analysis, stitching together two ideas about time under the logic of the causa or case. The 1599 De armis Romanis libri duo was comprised of two books, the Actio (accusation), part of which had been published in 1590 as De injustitia bellica Romanorum actio, and a new second part, the Defensio (defence). Each of the two books is written in a separate persona, and while one of Gentili's voices necessarily has the last word, neither receives sanction from an overarching authorial voice. ${ }^{66}$ Beyond the dedication to Essex, Gentili includes no authorial commentary in propria persona. Instead, a prosecutorial voice in the Actio arraigns the Roman empire for greed, deceit, war crimes, and unjust wars, after which Rome's advocate in the Defensio defends the wars of the Romans from the first book's charges chapter by chapter, point by point. In a representative passage, Book One insists 'The Romans wanted everything around them to lie open to themselves alone, and they brought this about by means of every possible crime. ${ }^{67}$ Book Two's replies yield nothing: 'our empire ... was sought out by just arms and preserved by just laws' ${ }^{68}$ Richard Tuck comments that the successive humanist disputations of De armis Romanis 'leave [...] the reader rather unclear about where the author stood, which, at the very least, should cast doubt on Condren's claim that an ambiguous Henry is historically implausible. ${ }^{69}$ Yet the shared grounds of debate in Gentili's 'forensic drama' are instructive as well. ${ }^{70}$ According to the editors of a recent English translation, 'Both the indictment of Roman imperialism in Book 1 of The Wars of the Romans and its defense in Book 2 are predicated on the assumption that it is apposite to judge the expansion of the Roman empire by way of warfare according to

${ }^{65}$ Sutherland and Watts, Henry V, War Criminal?, 110. To put the point in Keatsian terms, Shakespeare's famous 'negative capability' arises precisely at the moment of legal determination.

${ }^{66}$ Scholars including Diego Panizza and myself have found hints of the second book in Gentili's De iure belli, but David Lupher offers compelling qualifications. Diego Panizza, 'Alberico Gentili's De armis Romanis: The Roman Model of the Just Empire', in The Roman Foundations of the Law of Nations: Alberico Gentili and the Justice of Empire, ed. Benedict Kingsbury and Benjamin Straumann (Oxford: Oxford University Press, 2011), 53-84; Christopher N. Warren, 'Gentili, the Poets, and the Laws of War', in The Roman Foundations of the Law of Nations: Alberico Gentili and the Justice of Empire, ed. Benedict Kingsbury and Benjamin Straumann (New York: Oxford University Press, 2011); David Lupher, 'The De armis Romanis and the Exemplum of Roman Imperialism', in The Roman Foundations of the Law of Nations: Alberico Gentili and the Justice of Empire, ed. Benedict Kingsbury and Benjamin Straumann

(Oxford: Oxford University Press, 2011), 85-100.

67 Gentili, De armis Romanis, 111.

${ }^{68}$ Gentili, De armis Romanis, 355 .

69 Tuck, The Rights of War and Peace: Political Thought and the International Order from Grotius to Kant, 17.

70 Panizza, 'Alberico Gentili’s De armis Romanis: The Roman Model of the Just Empire', 59. 
certain moral normative criteria-indeed, denying or affirming the justice of the Roman empire is precisely what the Wars of the Romans is all about. ${ }^{71}$ The dedication of 1590 's De injustitia bellica Romanorum actio advertised that Gentili 'in this actio ... wished to treat of the rulings of the law ... and to make a disputation about the injustice of which the Roman people seems to be accused.72 International events up to two thousand years old came under Gentili's juridical scrutiny. As early as 1590, and then again in expanded form in 1599, Elizabethan readers had a formidable legal apparatus to assess relations among war, crime, and historiography.

Indeed, the first book's critique of empire hinged as much on historiography as on law. Gentili's actor (plaintiff) begins with a chapter-length assertion that 'The Truth of Roman History is Tainted. ${ }^{73}$ While Book 2, by contrast, defends a sanitized Roman history, insisting on what Shakespeare's Fluellen calls the 'pristine wars of the Romans' (3.3.26-7), the first book ensures that perspectives like Fluellen's will seem naively credulous. In Act 4 , Scene 1 Fluellen, at his most 'pedantic', tells Gower, ${ }^{74}$

It is the greatest admiration [i.e. astonishment] of the universal world, when the true and ancient prerogatifs and laws of the wars is not kept. If you would take the pains but to examine the wars of Pompey the Great, you shall find, I warrant you, that there is no tiddle-taddle nor pibble-babble in Pompey's camp. I warrant you, you shall find the ceremonies of the wars, and the cares of it, and the forms of it, and the sobriety of it, and the modesty of it, to be otherwise. (4.1.67-75)

Henry, disguised, overhears the exchange, and admits that it 'appear[s] a little out of fashion', but he finds 'much care and valor in this Welshman', a view the plot goes on to endorse when Fluellen's 'Welsh correction' teaches the nativist Pistol 'a good English condition' (4.1.83-4, 5.1.74-5). But Gentili's first book gives ample historical warrant to read Henry and Fluellen as complicit in using law and history for overblown claims of imperial virtue. Fleullen's is a past that makes normative claims on the present, and Henry notices. He tolerates it, however, because anachronism helps keep order in the camps. ${ }^{75}$ Fluellen, whose interest in 'a few disputations ... partly touching or concerning ... the Roman wars' again marks him as a reader of Gentili, has convinced some readers of his 'rigid adherence to law and precedent', but Shakespeare's dominant interest appears instead to be connecting Fluellen's type of legal historiography with self-justifying imperial aims (3.2.39-41). ${ }^{76}$ That the Roman people was holy, that the Roman

71 Benedict Kingsbury and Benjamin Straumann, 'Introduction: Roman Wars and Roman Laws', in The Wars of the Romans: A Critical Edition and Translation of De armis Romanis (New York: Oxford University Press, 2011), xi.

72 Gentili, De armis Romanis, 361.

${ }^{73}$ Gentili, De armis Romanis, 150.

74 Pugliatti, 'The Strange Tongues of Henry V', 249.

75 'Zealous justification' must not be mistaken for 'historical trustworthiness' according to Gentili, $D e$ armis Romanis, 127.

${ }^{76}$ Camille Wells Slights, 'The Conscience of the King: Henry V and the Reformed Conscience,' $P Q$, 80.1 (2001): 53 . 
people was beautiful, that the Roman people was invincible, and that the Roman people flourished with every sort of excellence,' Gentili's actor admonishes, 'this and other stuff of that sort, we have imbibed with the most attentive eyes, and drawn by the semblance of the authors' consummate erudition and seduced by their soothing speech, we have taken it on trust and been deceived by it. ${ }^{37}$ In such cases, historiography has been little more than encomiastic poetry.

Poetry itself, meanwhile, has been improperly taken for truth. Poetic flights of the kind mimicked to the point of parody by Henry V's Chorus, ensured 'an excellence became believed that in fact lay far from true excellence-very far indeed, for if we pay attention to the praised hero's actual doings ... we do not stand stupefied and amazed at the praises. ${ }^{18}$ Here we can return to Shakespeare's distinctive interest in 'dramatizing rather than concealing ... the literary act which re-creates the event'-the spirit too of Gentili's first book. If Roman poets, according to Book 1, 'wrote of ... deeds in such a way as to pass over disasters', Shakespeare uses the Chorus to translate the politics and contingency of historiography into a formal register in which acts of passing over cannot be overlooked. When the Chorus says in the prologue, "tis your thoughts that now must deck our kings, / Carry them here and there, jumping o'er times', the lines manufacture a sense of disequilibrium, creating both a surplus of event-ness and also a lack (28-9, emphasis mine). History is too big to be reduced to a single play and the present is too short to reproduce history: through the serial mediations of the Chorus, audiences are asked to perceive too much history and not enough now. If stupefaction in the face of quietly sanitized history here opens into the jurisdiction of the sceptical interpreter, it does so in part by freeing Shakespeare's Henry from the strictly historical register and translating him into a self-consciously contemporaneous forum where he is visibly remade and judged anew.

Henry V's hints of priestly collusion in an unjust war echo Gentili's third chapter of Book One, where he addresses the history of the Roman fetial priests, the religious order responsible for promulgating and transmitting the fetial laws, the Roman laws of war. The story Gentili recounts is that of Ancus, who 'censured his predecessors because he is said to have seen that the Roman people was passionate with love for wars and ready to inflict war upon peoples when there was no just cause, and so he adopted the fetial laws ... as a remedy to this injustice. ${ }^{79}$ 'But are to we call it a remedy-or rather a sticking plaster or rouge?', writes the accuser. He quotes one of his favourite sources, the church father Lactantius, saying, 'Just how far the utility stands from justice the Roman people itself teaches us, for by declaring wars through the fetial priests and imposing wrongs under the cover of law and by always craving and plundering other peoples' things they acquired for themselves possession of the entire world. ${ }^{30}$ The search for religious

77 Gentili, De armis Romanis, 9.

78 Gentili, De armis Romanis, 49.

79 Gentili, De armis Romanis, 35 .

${ }^{80}$ Gentili, De armis Romanis, 35 . 
justification returns in the sixth chapter of Book One, where the speaker denounces the 'religious excuses and subterfuges' underpinning Roman aggression. ${ }^{81}$

Irish, Welsh, and Scottish contexts that have long interested postcolonial critics of Henry $V$, and that animate several presentist critics, likewise grow even richer through Gentili's antithetical accounts of Roman empire. ${ }^{82}$ Henry's proto-British army, which includes not only the Welsh Fluellen but the Scots Jamy and the Irish MacMorris, ensures that the dramatized past cannot be artificially cut off from the imperial concerns of the 159os. Fleuellen, it's been observed, 'figures the colonial subject who has internalized English values and subordinated his own provincial loyalties to service to the English nation-state. ${ }^{83}$. If Fluellen 'represents the already safely assimilated Celt', the Irish and Scots warriors who have smaller roles remain satellites of English power. ${ }^{84}$ The play's many allusions to Rome invite us see this dynamic in the context of imperial processes transhistorically applicable to Rome and the British archipelago. Both of Gentili's speakers agree that Rome was founded as a 'wide-open asylum ... for any and all of the most desperate men. ${ }^{85}$ Yet 'men diverse in language and discordant in customs' are a mark of opprobrium for the first speaker, a mark of honour for the second. The voice in the second book declares that 'Before long, men who had at first streamed together from various polities, diverse in languages, discordant in their manners, coalesced into one state through shared practices and language. ${ }^{, 86}$ The accuser instead speaks of a 'contagion' in which 'the process went one from one group of people to the next, and when whatever peoples were nearest had been seized, [the Romans] reduced all of Italy to [their] power. ${ }^{87}$ Even here, according to the critique, historiography intervenes, for the question wasn't whether the speaker should 'mention other Italian peoples oppressed by the unjust arms of the Romans' but 'how'. The difficulty was precisely the one Shakespeare highlights with his Chorus-the gaps that inhibit secure historical knowledge. 'Placed as we are at such a remote distance in time, we can only know the misdeeds of the Romans through those who have praised the Romans. ${ }^{98} \mathrm{~A}$ character

81 Gentili, De armis Romanis, 53.

${ }^{82}$ For Celtic contexts, see Lorna Hutson's essay in this volume and, inter alia, Philip Schwyzer, “ "I Am Welsh, You Know?": The Nation in Henry V', in Literature, Nationalism, and Memory in Early Modern England and Wales (Cambridge: Cambridge University Press, 2004); David J. Baker, " "Wildehirissheman": Colonialist Representation in Shakespeare's Henry V', ELR, 22.1 (December, 1992): 37-61; Highley, Shakespeare, Spenser, and the Crisis in Ireland. On presentism and contemporary questions of devolution, see Hawkes, Shakespeare in the Present, 4, 23-65. On postcolonialism as presentism 'in principle if not in name', see Hugh Grady and Terence Hawkes, 'Introduction: Presenting Presentism', in Presentist Shakespeares (New York: Routledge, 2007), 5.

${ }^{83}$ Highley, Shakespeare, Spenser, and the Crisis in Ireland, 147.

${ }^{84}$ Richard Dutton, " Methinks the Truth Should Live from Age to Age': The Dating and Contexts of Henry V', HLQ, 68.1-2 (2005): 194.

85 Gentili, De armis Romanis, 19.

86 Gentili, De armis Romanis, 135 .

87 Gentili, De armis Romanis, 163 . See further Lupher, 'The De armis Romanis and the Exemplum of Roman Imperialism', 92-3.

${ }^{88}$ Gentili, De armis Romanis, 59. 
like Fluellen on this reading is 'safely assimilated', but his subaltern praises of Henry speak doubly as admiration and critique.

\section{Conclusion}

I have been suggesting that Gentili's De armis Romanis offers insights into several of the formal features of Shakespeare's play and that Shakespeare and Gentili engaged in a common project of transforming events of empire, whose role was to be narrated, into cases of empire, whose function was to be judged. Accepting Anne Orford's insight that international legal method is fundamentally the 'art of making meaning move across time', I have aimed to illuminate the contingent historicity of that art by attending to early modern writers' own strategies for maintaining traffic between past and present in the face of an emerging historicism. ${ }^{89}$ Far from presenting the past as impervious to legal analysis, Shakespeare and Gentili deployed genres that charged the past with juridical salience, preserving an association between international history and 'juridical thinking' and contributing to a distinctive historicism within international law. ${ }^{90}$ Not only is it legitimate to ask whether Henry was a war criminal; it is historically appropriate to do so.

This account still leaves many questions unanswered, but the one with which I propose to conclude is this: why would the question of war crimes in Henry $V$ seem anachronistic in the first place? My answer concerns a second type of international legal historiography distinct from the Renaissance philosophy of history newly revived in critical legal history. As scholars including Martii Koskenniemi and Mark Mazower have shown, progressivist nineteenth-century legal historiography has profoundly influenced perceptions of the international past. ${ }^{91}$ History, as Kant put it in a 1784 essay, had a cosmopolitan purpose. Successive thinkers, invested as Kant was in various contrasts between civility and barbarousness, engaged in a highly political project intended to formalize international legal rules and to unify disparate legalities. Figures from Robert Ward in 1795 to Henry Sumner Maine in 1887 drew energy for contemporary projects by positing a barbarous history soon to be overcome. ${ }^{92}$ Victories, including the Geneva Conventions of 1864, and Hague Convention of 1899, were won in part as Whiggish advocates presented a history of the slow coming to consciousness of the unity of the law as a reflection of humanity's moral identity. ${ }^{93} \mathrm{New}$ institutions were

89 Orford, 'On International Legal Method', 172.

90 Orford, 'On International Legal Method', 166.

${ }_{11}$ Martti Koskenniemi, The Gentle Civilizer of Nations: The Rise and Fall of Modern International Law, 1870-1960 (New York: Cambridge University Press, 2001); Mark Mazower, Governing the World: The History of an Idea (New York: Penguin Press, 2012), 65-94.

${ }_{92}$ Martti Koskenniemi, 'A History of International Law Histories', in The Oxford Handbook of the History of International Law, ed. Bardo Fassbender and Anne Peters (Oxford: Oxford University Press, 2012), 943-71.

${ }^{93}$ Koskenniemi, 'A History of International Law Histories', 959. 
proposed as remedies to what one writer called the "bloody and savage customs of the Middle Ages. ${ }^{94}$

Like Fleuellen and Henry, nineteenth-century historians of international law profaned the past by making it serve present needs, yet their error wasn't anachronism but the equal and opposite one for which we have no name. Any difficulty critics have in recognizing war crimes in Shakespeare-indeed thinking about international law in the early modern period more broadly - follows in no small part from rarely examined suppositions about international history and its relation to international law.

\section{BIBLIOGRAPHY}

Bodin, Jean. Method for the Easy Comprehension of History, trans. Beatrice Reynolds (New York: W. W. Norton and Co., 1969).

Camerlingo, Rosanna. 'Henry V and the Just War: Shakespeare, Gentili and Machiavelli', in Machiavellian Encounters in Tudor and Stuart England: Literary and Political Influences from the Reformation to the Restoration, ed. Alessandro Arienzo and Alessandra Petrina (Burlington: Ashgate, 2013), 103-19.

Condren, Conal. 'Understanding Shakespeare's Perfect Prince: Henry V, the Ethics of Office and the French Prisoners', in The Shakespearean International Yearbook 9, ed. Graham Bradshaw, Tom Bishop, and Laurence Wright (Burlington: Ashgate, 2009), 195-213.

Fasolt, Constantin. The Limits of History (Chicago: University of Chicago Press, 2004).

Gajowski, Evelyn. 'Beyond Historicism: Presentism, Subjectivity, Politics', Literature Compass, 7.8 (2010): 674-91.

Gentili, Alberico. The Wars of the Romans: A Critical Edition and Translation of "De armis Romanis", ed. Benedict Kingsbury and Benjamin Straumann, trans. David Lupher (New York: Oxford University Press, 2011).

Gordon, Gregory S. 'The Trial of Peter von Hagenbach: Reconciling History, Historiography, and International Criminal Law', in The Hidden Histories of War Crimes Trials, ed. Kevin Heller and Gerry Simpson (Oxford: Oxford University Press, 2013), 13-49.

Hawkes, Terence. Shakespeare in the Present (London and New York: Routledge, 2003).

Hutson, Lorna. 'Imagining Justice: Kantorowicz and Shakespeare', Representations, 106.1 (May, 2009): 118-42.

Koskenniemi, Martti. 'Vitoria and Us: Thoughts on Critical Histories of International Law', Rechtsgeschichte Legal History-Zeitschrift Des Max-Planck-Instituts Für Europäische Rechtsgeschichte, 22 (2014): 119-38.

Meron, Theodor. Henry's Wars and Shakespeare's Laws: Perspectives on the Law of War in the Later Middle Ages (Oxford: Oxford University Press, 1993).

Orford, Anne. 'The Past as Law or History?: The Relevance of Imperialism for Modern International Law', International Law and Justice Working Papers 2 (2012).

Orford, Anne. 'On International Legal Method', London Review of International Law, 1.1 (September, 2013): 166-97.

Parfitt, Rose. 'The Spectre of Sources', European Journal of International Law, 25.1 (February, 2014): 297-306.

${ }^{94}$ Quoted in Koskenniemi, 'A History of International Law Histories', 952. 
Pugliatti, Paola. Shakespeare and the Just War Tradition (Burlington: Ashgate, 2010).

Rousso, Henry. The Haunting Past: History, Memory, and Justice in Contemporary France, trans. Ralph Schoolcraft (Philadelphia: University of Pennsylvania Press, 2002).

Schwarzenberger, Georg. International Law as Applied by International Courts and Tribunals: The Law of Armed Conflict, 2 vols (London: Stevens, 1968).

Stevens, Paul. "The New Presentism and Its Discontents: Listening to "Eastward Ho" and Shakespeare's "Tempest" in Dialogue', in Rethinking Historicism from Shakespeare to Milton, ed. Ann Baynes Coiro and Thomas Fulton (Cambridge: Cambridge University Press, 2012), $133-58$.

Sutherland, John, and Cedric Thomas Watts. Henry V, War Criminal?: And Other Shakespeare Puzzles (Oxford: Oxford University Press, 2000).

Tuck, Richard. The Rights of War and Peace: Political Thought and the International Order from Grotius to Kant (Oxford: Oxford University Press, 1999). 


\title{
THE OXFORD HANDBOOK OF
}

\section{ENGLISH}

LAW AND

\section{LITERATURE,}

\section{$1500^{-1700}$}

\author{
Edited by \\ LORNA HUTSON
}




\section{OXFORD \\ UNIVERSITY PRESS \\ Great Clarendon Street, Oxford, $\mathrm{OX}_{2}$ 6DP, United Kingdom}

Oxford University Press is a department of the University of Oxford. It furthers the University's objective of excellence in research, scholarship, and education by publishing worldwide. Oxford is a registered trade mark of

Oxford University Press in the UK and in certain other countries

(c) the several contributors 2017

The moral rights of the authors have been asserted

First edition published in 2017

Impression: 1

All rights reserved. No part of this publication may be reproduced, stored in a retrieval system, or transmitted, in any form or by any means, without the prior permission in writing of Oxford University Press, or as expressly permitted

by law, by licence or under terms agreed with the appropriate reprographics rights organization. Enquiries concerning reproduction outside the scope of the above should be sent to the Rights Department, Oxford University Press, at the address above

You must not circulate this work in any other form and you must impose this same condition on any acquirer

Published in the United States of America by Oxford University Press 198 Madison Avenue, New York, NY 10016, United States of America

British Library Cataloguing in Publication Data Data available

Library of Congress Control Number: 2016961439

ISBN 978-0-19-966088-9

Printed and bound by

CPI Group (UK) Ltd, Croydon, CRo 4 YY

Links to third party websites are provided by Oxford in good faith and for information only. Oxford disclaims any responsibility for the materials contained in any third party website referenced in this work.

I owe an enormous amo have been conceived or $t$ shape as papers present Legal Imaginary, $1500-1$ Universities of Princetor first of these and co-host thought well known to $r$ the interdisciplinary con

I would also like to tha ously commissioning thi throughout. I am please and History at Princeto for Mediaeval and Early St Andrews for support and friendships there be chapters of this book. Th into print. I am grateful Andrews conference, anc was shared at an early st to this Handbook. Their and their subsequent pat whole project a pleasure.

Among more particula The historian Christophe how crucial to the social distinctive legal instituti the scholarly communit I am therefore very grate league and friend, for loc Mediaeval and Early Mo for this book. Thanks are helping reconstruct $\mathrm{Chri}$ answering queries.

In all that I have said, $\mathrm{t}$ ] at St Andrews has feature 